'SUPRANATIONALISM' IN QUESTION. BELIEFS, VALUES, AND THE SOCIALIZING POWER

OF THE EUROPEAN COMMISSION REVISITED

\author{
Sara Connolly* and Hussein Kassim** \\ *Professor in Personnel Economics \\ Norwich Business School \\ University of East Anglia, Norwich Research Park \\ Norwich, NR4 7TJ \\ United Kingdom \\ Tel: +44 (0) 16035943410 \\ email: sara.connolly@uea.ac.uk \\ ** Professor in Politics \\ PPL and Centre for Competition Policy \\ University of East Anglia, Norwich Research Park \\ Norwich, NR4 7TJ \\ United Kingdom \\ Tel: +44 (0) 16035943476 \\ email: h.kassim@uea.ac.uk
}




\begin{abstract}
Do international organizations affect the views of the people who work for them?

Although increasingly sophisticated methods have been used to address this question, disagreement persists about whether the beliefs of staff are formed before or after they enter the institution, or shaped by instrumental calculation. Drawing on an original dataset based on the first fully representative survey of the European Commission's workforce, this article breaks new ground by putting different definitions of 'supranationalism' to the test and by capturing multiple ways in which individuals may be affected by the experience of working for the organization. For the first time, it demonstrates that commitment to 'supranationalism' varies between Commission staff groupings, that the influences on belief vary with the measure of 'supranationalism' used, and that both post-recruitment experience and pre-recruitment roles play a part in shaping beliefs.
\end{abstract}

Keywords: European Commission, socialization, international civil servants, values, beliefs, supranationalism 


\section{'SUPRANATIONALISM' IN QUESTION. BELIEFS, VALUES, AND THE SOCIALIZING POWER OF THE EUROPEAN COMMISSION REVISITED}

\section{Sara Connolly and Hussein Kassim}

What bureaucrats believe and what shapes their beliefs have been long-standing preoccupations in the practice and the study of public administration. In this context, international civil servants have commanded particular attention. In a literature spanning several disciplinary fields (see Pollack 1998; Checkel 2005; Scully 2005), interest has focused on the extent to which staff express the organizational values embodied by their institutions.

In the case of the European Union (EU), the socializing power of the European Commission over its staff went unquestioned for four decades. It was confidently asserted not only that the Commission would be populated by pro-Europeans, eager to expand EU competencies and therefore their own power, but that their zealous proEuropeanism would be contagious. Indeed, successive versions of neofunctionalism, a classic theory of European integration, identified the communication by Commission officials of supranational values to national political and economic elites as a key dynamic of that process (Haas 1958: 17, Lindberg 1963: 84).

These assumptions were first challenged in the late 1990s, confirmed in later work (Hooghe 2002, 2005, Dehousse and Thompson 2012, Kassim et al 2013: ch 4), when empirical investigation revealed variations in the views held by Commission staff (Hooghe 1999a, 1999b). Three explanations accounting for the views held by 
Commission officials emerged in the new wave of literature that followed Hooghe's landmark research. According to the first school, which quickly became the dominant wisdom, the pre-recruitment experience of staff is decisive (Hooghe 1999a, 1999b, 2002, 2005; Bes 2013). The values of the individuals who form its workforce are formed within national environments before they ever enter the Commission. A second perspective contests the first and argues, to the contrary, that post-recruitment experience -- specifically, the working environment in the Commission -- does have an impact on the loyalties of staff (Trondal 2006, 2007). For the third, inspired by public choice accounts, employee preferences are shaped by self-interest (Bauer 2012, Kassim et al 2013: ch 4). In addition, several hybrid approaches combine elements of these three perspectives. Murdoch and Geys (2012), for example, links behavioural role criteria from the second to the instrumental cost-benefit calculation of the third.

Despite the important insights it offers, however, the new wave of scholarship exhibits three major shortcomings. The first concerns the dependent variable. Authors take commitment to 'supranationalism' as the assumed outcome of socialization in the Commission and an indicator of the Commission's socializing power. Although the term is central to their inquiry, scholars rarely reflect on its precise meaning or quality. Yet whether 'supranationalism' is a preference for a particular form of governance, a motivation, or a conception of the Commission's role, is a fundamental question. In addition, the measures of 'supranationalism' scholars use are often oblique. As a result, the operationalization of the term frequently arrives at a construct that lies at some distance from the values actually registered by respondents. 
The second shortcoming relates to the narrow sample on which existing studies are founded. The literature typically reports findings based on data relating to a small number of individuals or to a particular subgroup within a staff category. Even setting aside other relevant characteristics, such as level of seniority, nationality, gender or location, which are important to ensuring that a sample is representative of the organization's population, such an approach neglects the differentiated composition of the Commission workforce. Staff belong to different formal categories -- they are administrators, assistants, temporary agents, contract agents and seconded national experts - and occupy a position ('grade') in a hierarchy within those groupings. 'Administrators', for example, encompasses senior and middle managers in high grades, and policy officers in non-management roles in lower grades. Other groupings, for example, temporary agents, include both cabinet members, who work at the peak of the organization on the political frontline, and individuals drafted in to cover short-term staff shortages at all levels. Figure 1 illustrates the main staff groupings in the Commission (see also Connolly and Kassim 2015: Table 10.2).

\section{FIGURE 1}

A further complication arises from the fact that a proportion of administrators and assistants are on temporary contracts. Thus, a distinction between permanent and temporary staff cuts across, rather than coincides neatly with, staff groupings. In a differentiated organization, samples need to be constructed with considerable care if analyses are to be generalizable. Reliance on a single staff grouping or subgrouping is likely to have limited value at best. Moreover, since they focus largely on a single staff 
grouping or subgrouping, existing studies cannot register or measure variation between staff groupings. They cannot establish whether or to what extent the beliefs, values and experiences they report are representative of the Commission workforce as a whole.

The third limitation concerns the range of independent variables tested in earlier studies. This shortcoming is partly related to the narrowness of the samples on which they are based and partly their homogeneneity, which leaves the influences shared between individuals within them undetected. Furthermore, the existing literature places a strong emphasis on some variables, such as nationality, but it omits other potentially important socialising factors, such as work location, staff grouping, horizontal mobility, and cabinet experience.

Informed by analysis of a new dataset covering the entire workforce, this article addresses these limitations. It aims to advance knowledge in three ways. First, it argues in favour of a broader definition of the possible organizational values that may result from working in the Commission. Second, based on this new empirical evidence, the article shows for the first time that the beliefs and values of Commission employees vary between staff categories, sometimes significantly. Third, the paper challenges the dominant orthodoxy in the literature; namely, that pre-recruitment socialization is decisive in shaping the values and beliefs of Commission staff. The richness of the dataset makes it possible to test the beliefs and values of Commission staff in a diverse range of settings, and therefore to detect how a wider set of experiences may influence what they believe.

This article thereby aims to contribute to the literature in two ways: by 
highlighting and addressing three major shortcomings of the existing literature; and by providing a new approach to the above debate, new knowledge of what staff across the Commission believe, and a new understanding of the experiences that shape the beliefs of Commission staff. Although the issue of whether its power has waxed or waned is keenly disputed, the Commission retains a central position in the EU system. By offering insights into whether and if so, to what extent, working in the Commission affects the beliefs, values and outlooks of its staff, this article both advances understanding of an important institution, and contributes to long-standing debates concerning the socializing power of international institutions.

The discussion that follows is organized into two parts. The first reviews how scholarship on the beliefs of Commission staff has developed, summarizes the approaches taken by existing studies, and offers a critical analysis of the literature. The second introduces 'Facing the Future' -- the project from which the dataset analysed in this article is drawn -- and discusses how it addresses the limitations of existing scholarship. It describes the data that were collected for the project, as well as the questions posed in the survey, and outlines the empirical model and hypotheses. After setting out the findings, it examines the significance of the research for earlier studies, and considers the wider implications of the results for the field.

\section{EU staff, beliefs and the existing literature}

What the staff of EU institutions believe has been an issue of major concern in the postwar institutionalization of Europe. While Jean Monnet argued that the European 
administration should be composed of dedicated technocrats, Haas defined integration as 'the process whereby political actors in several distinct national settings are persuaded to shift their loyalties, expectations and political activities towards a new centre (1968: 16) and argued that the dissemination of values from the Commission was a key dynamic in advancing that process. Three decades later, heralding the rise of a social constructivist perspective in the study of the EU, Christiansen et al (1999: 529) inferred that since 'European integration has a transformative impact on the European state system and its constituent units . . it is reasonable to assume that in the process agents' identity and subsequently their interests have equally changed'.

An early assumption was that Commission officials would be 'supranationalist' in outlook. Although the specific content of the term often went undefined, the view that Commission personnel share a particular outlook associated with the organization's mission came to be shared by scholars working from different theoretical perspectives, including rational choice (see, e.g., Pollack 2003, Jupille 2004, Franchino 2007). Even though this view has been contested by arguments that the Commission is better conceptualized as a 'multi-organization' (Cram 1993) than a monolith, the belief that the Commission is populated by competence-maximizers persists as a convenient simplification.

In a new wave of scholarship emerging in the late 1990s scholars put assumptions made by the classic literature, many of which had become accepted wisdoms beyond the academy (Kassim et al 2013: chs 1, 3), to empirical test. Whereas the earlier literature had tended to 'black box' the Commission, the new generation of 
scholars sought to penetrate its inner workings and to explore the beliefs of its personnel. Though they agreed that the Commission was not a 'citadel of supranationalism' (Dehousse and Thompson 2012), these scholars adopted different explanatory perspectives. Three main schools emerged -- pre-recruitment socialization, post-recruitment socialization, and positional advantage - as summarized in Table 1.

TABLE 1

\section{Pre-recruitment socialization}

Based on the pioneering work of Hooghe, this first school contends that pre-recruitment influences are decisive. Arguing that '[O]ur understanding of European integration remains poor at best, and possibly mistaken, if we fail to account for the motivations and opinions of key position holders in the European institutions' (1999: 436), Hooghe sought to examine the orientations of senior officeholders in the Commission. Her conclusion, tested against three datasets collected between 1995 and 2008, is that 'international socialization' - experience within the Commission -- has a relatively limited effect on the role conceptions of senior officeholders and that senior officeholders acquire their beliefs and values in their home state before entering the Commission (Hooghe 1999a, 1999b, 2002, 2005, 2012).

Why does national background matter more than other influences? Hooghe offers two explanations. The first is that formative experiences occur early in life. Since Commission employees typically enter the organization in their early thirties, their 
values have already been shaped. The second is that, because they work in a political context where territoriality is key marker of interest and mobilization, national cues are reinforced when Commission staff interact with representatives of the European Parliament, the Council, and other actors. The key national variables are the type of territorial order, i.e. unitary or federal, size, and whether the staff member was employed as a civil servant.

Hooghe's central findings have recently been re-asserted by Bes (2013). After making a number of refinements, such as re-working Hooghe's original typology, filtering the sample to avoid double-counting, and remodelling the measurement of respondent choices - Bes finds, first, that national background and political ideology are the best predictors among the variables tested and, second, that variables associated with post-recruitment socialization have little or no impact. Suvarierol et al (2013) also find in favour of a pre-recruitment socialization approach. However, because they extend the term to include the processes of recruitment to EU institutions, they contradict Hooghe's emphasis on national experience.

\section{Organizational socialization}

The second perspective, developed by Trondal (2001, 2006, 2007, 2008), sometimes with co-authors (Trondal et al 2008; Murdoch and Trondal 2013), contests the presocialization approach and insists that working for the Commission does have an influence. Adopting a 'least likely case' approach, Trondal tests the Commission's socializing capacity by examining the loyalties or role conceptions of seconded national 
experts (SNEs). The assumption is that, since their beliefs are forged in their home states and they will return to their national administrations, SNEs are unlikely to exhibit 'supranationalist' values unless socialized by their experience in the Commission (Trondal 2001: 4; 2007: 1112; 2010: 75).

Drawing on survey and interview data, Trondal (2007:1112) finds that 'SNEs evoke multiple roles', departmental, epistemic and supranational. His analysis 'reveal[s] that actor-level supranationalism among SNEs reflect (i) processes of re-socialization inside the Commission, (ii) the organizational composition of the Commission and (iii) organizational incompatibilities between the Commission and domestic government institutions'. As such, they 'challenge a core claim of Hooghe (2005)'; namely, 'that socialization of Commission officials mainly occur[s] at the national level and not inside the Commission apparatus' (ibid).

Combining 'insights from middle-range social constructivist, institutionalist and organization theory approaches', Trondal (2007) develops 'a composite institutional approach' to explain the variance in actor level supranationalism. According to the first, post-recruitment socialization depends on the length of time an employee works in the Commission and/or on the intensity of interaction with Commission colleagues. The second contends that, since the cognitive scripts they encounter when they join the Commission challenge SNEs to shift from an old to a new role conception, SNEs whose new area of responsibility differs markedly are more likely to be strongly 'supranationalist'. 


\section{Positional advantage}

Public choice theory is the inspiration for a third perspective, which explains the beliefs exhibited by bureaucrats in terms of self-interest. Hooghe tests four hypotheses derived from public choice assumptions: that officials in powerful Directorate-Generals (DGs) are likely to be more 'supranational' because regulatory and financial authority will strengthen them (Hooghe 2002: 104); that staff from countries that are net beneficiaries from EU membership are likely to be more 'supranational'; that EU civil servants from countries with strong informal (i.e. national) networks in Brussels are likely to be more intergovernmental, since these networks are a resource for professional success (2001: 105); and that SNEs are likely to be more intergovernmental, since they owe their selection to national governments and will return home after their temporary spell in the Commission (2001: 106). She finds evidence for the first three in her 2002 book, but not her 2005 article. Bauer (2012) and Kassim et al (2013: ch 8), meanwhile, also find evidence that utility-maximization, understood in terms of career prospects and departmental interests, is an important explanatory variable, but their findings are linked explicitly to attitudes to reform and they do not suggest that utility maximization applies more generally.

Murdoch and Geys (2012) develop a hybrid approach, which assumes the coexistence of multiple logics of social action. Following Trondal (2006), they argue that the values of SNEs are shaped partly by the role they play within the Commission and how strongly they identity with four behavioural roles (epistemic, sectoral, national and supranational) and partly an instrumental calculation, which can be measured in terms 
of an explicit aim to further their career possibilities. They find evidence that the behaviour of SNEs is influenced both by role expectations and cost-benefit calculations.

\section{Critical reflection}

Although it has significantly advanced understanding of the Commission and its staff, the new empirically-based literature has three important weaknesses. First, it pays surprisingly little attention to the definition of the dependent variable. Authors rarely offer a justification for their preferred formulation or, despite different usages, discuss the relative merits of different definitions. Not do they consider the downsides of their favoured option. For Hooghe (1999a, 1999b, 2005, 2011), 'supranationalism' is an orientation towards European integration, while for Trondal it is based on 'loyalty to the Commission and to the Director General' $(2006,2007)$. Yet the first fails to distinguish between 'federalists' and supporters of the 'Community method', and does not explain why preference for a particular form of governance should be taken as a test for determining whether working for the Commission leaves it mark on an individual. In respect of the second, meanwhile, no explanation is offered for why felt affiliation to a senior manager should be considered a measure of 'supranationalism'.

Moreover, the definitions of 'supranational' in the new literature do not always map easily or obviously onto the values expressed by respondents. The pre-recruitment socialization approach constructs its measure from responses to two proxies: whether member states should be the central pillars of the EU; and whether the Commission should be the government of the EU (Hooghe 2005: 889). Yet deriving a measure of 
'supranationalism' from these two propositions is problematic. It is not only unclear that they generate a meaningful continuum, but it is debatable whether the results of four distinct binary choices can be read as a single four-way choice.

Second, existing studies are based on data from small unrepresentative samples. The pre-recruitment perspective, for example, draws on a small number of 'senior officials', either senior managers or heads of cabinet. Both are small subpopulations, and each a sub-grouping of a wider staff category -- administrators in the case of senior managers and temporary agents in the case of heads of cabinet. Moreover, even senior managers can be on temporary contracts, so are not necessarily 'permanent officials', while heads of cabinet, although employed as temporary agents for the period that they are in the Commissioner's private office, may be seconded internally from among the Commission's permanent staff or may come from outside the organization. SNEs, by contrast, who feature centrally in the writings of the postrecruitment school, constitute only around 2 per cent of the Commission's workforce. Neither school can explore differences between staff groupings, or measure variation across the Commission workforce, limitations that severely inhibit the granularity of their findings and the generalizability of their conclusions.

Third, although the existing literature examines the effects of a significant range of independent variables, important potential influences, such as staff grouping, contractual status, workplace location, and the number of DGs in which an employee has served, remain untested. It is not possible from reading Hooghe (1999, 2002, 2005), for example, to know whether permanent staff are likely to be more 'supranational' 
than those on temporary contracts. Trondal, meanwhile, as Bes notes (2013: 6), highlights the importance of international education as a source of pre-recruitment socialization, but does not always test for its impact. The failure to include these variables, combined with the tendency to concentrate on a single staff category or segment of staff, restricts the ability to detect the impact of potential influences and limits the range of organizational experience that is tested.

In summary, existing studies offer important, but partial, insights into the beliefs of the Commission workforce. Different definitions of 'supranationalism' are used, but never critically examined, the representativeness of the populations investigated is questionable, and key variables, most notably staff grouping, but also location, are untested. 'Facing the Future' was designed to address and, where possible, to transcend these limitations.

\section{A new approach to what Commission staff believe}

Against the background of this debate, and using the opportunity afforded by the scope and scale of the new dataset, this article has three main ambitions. The first is to examine the values of Commission staff across the organization -- in all staff categories and at all levels. The aim is to map the extent to which similar views are shared by employees across different staff groupings.

The second, revisiting the central question of the Commission's socializing power, is to establish whether the experience of working in the Commission has an impact on the beliefs and values of staff. The dataset offers the opportunity to assess 
whether the claims made by the three schools hold when tested against all staff categories. Because it is drawn from a sample that is representative of the Commission workforce in several key respects, it allows aspects of organizational experience that may affect the beliefs and values of Commission employees to be assessed for the first time, and new independent variables to be tested, in addition to re-running hypotheses from the existing literature.

Third, the article introduces a broad test for 'supranationalism'. Alongside a more direct, intuitive and precise test for commitment to 'supranationalism' as a form of EU governance, the article includes two additional measures. It extends the scope of 'supranationalism' to include a wider range of pro-European sentiments that working for the Commission might engender. Used with a larger and more representative sample, this makes it possible to explore whether 'supranationalism' finds varied forms of expression among the sub-populations of the organization.

\section{Data, method and hypotheses}

The research team used an online survey to solicit the beliefs of staff, as well as information about their educational and professional backgrounds, employment histories, work location, staff grouping, gender and nationality. Although interviews and focus groups were also conducted as part of 'Facing the Future', this article draws on data from the survey only. A link (in English, French and German) was emailed to 31,280 members of Commission staff on 21 March 2014. The survey remained open for four weeks and was completed by 5,545 respondents, representing a response rate of 17.7 
per cent. The achieved sample was benchmarked against the Commission population. The resulting weighted sample is representative of the Commission workforce by staff category, location, gender, cohort and national origins by old (i.e. pre-2004) or new (i.e. 2004 or after) member state, detailed in Appendix Figures 1a-1d.

'Supranationalism' was investigated using three different questions or measures. The rationale was that an expanded definition would make it possible to capture different ways in which 'supranational' commitment can be expressed. The first sought to investigate individuals' preferred vision of the EU. Asking staff 'Where would you place yourself on the question of European integration?', it invited respondents to locate themselves on an eleven-point scale where 0 represents 'a union of sovereign states' and 10 'an EU supranational state'. Respondents were thus able to express their views in a form that yielded immediately reportable values.

The second question focused on motivation. The rationale was that asking staff about their reason for working for the Commission would prompt respondents to reveal whether the opportunity to contribute towards building Europe was what motivates them. Asking 'Why did you choose to follow a career in the Commission?', respondents were offered a series of options - 'working in an international environment', 'commitment to Europe', 'competitive remuneration', 'job stability', 'commitment to a particular policy area' - and invited to indicate whichever applied to them.

Inspired by the classic public administration literature (Aberbach et al 1981), the third question asked respondents about their role conceptions as Commission employees. The idea was to test whether, and if so to what extent, staff members see 
their daily work in the Commission as advancing the European idea. Respondents were presented the proposition, 'As an employee of the Commission, I see my role above all else, as working for the interests of the $\mathrm{EU}^{\prime}$ and asked whether they strongly agreed, agreed, neither agreed nor disagreed, disagreed, strongly disagreed, or did not know. Following Suvarierol et al (2013), the phrasing was taken directly from the Staff Regulations, which define the rights and obligations of personnel working for the EU institutions. By framing 'role conception' in terms of the individual rather than the organization this question sought to discover how staff members see their job rather than simply inviting a re-affirmation of the Commission's vocation.

The use of three measures allowed researchers to capture a broader range of indicators than permitted by the single dimensional approach taken in the existing literature. It also made it possible to test whether, and if so, to what extent, responses to the three questions co-vary. If they do, it would follow that the three formulations are equally valuable as measures of adherence to the Commission's organizational values. If they do not, it would show that the definition of the dependent variable does matter and that scholars need to justify their particular choice.

The results of the 2014 'Facing the Future' survey questions are shown in Figures 2, 3 and 4. Summarising briefly, the average on the first question, 'Where would you place yourself on the question of European integration?', was 5.85 and the standard deviation 2.7. All eleven points on the scale were used. The modal response is 7 followed by 8 -- 1017 and 900 out of 5107 respectively. There is some variation by staff category, with managers more likely to locate themselves towards the 'EU as a 
supranational state', and a big difference between men and women, with men leaning more strongly towards the supranational end of the scale. On the second question, 'Why did you choose a career in the Commission?', the most frequently cited motivation was 'commitment to Europe' (61 per cent). Men were more likely than women and administrators, especially managers, more likely than respondents in other staff categories to give this response. On the third question, no fewer than 90 per cent of staff agree or strongly agree that 'As an employee of the Commission, I see my role above all else, as working for the interests of the EU'. Contract agents, staff from the EU13 and recent recruits are slightly less likely to agree.

FIGURES 2, 3 and 4

In the next stage of the analysis, a series of hypotheses derived from the three schools described above were tested with a view to determining the extent to which proEuropean organizational values vary by national background, pre-Commission socialization, experience within the Commission. To retain comparability with earlier literature, the explanatory variables were similar to those used in previous studies. Appendix Table 1 includes a full list of definitions, sources and descriptive statistics. Kassim et al. (2013: 19-30, especially Table 1.2) and Hooghe (2002) discuss the context and operationalization of key explanatory variables. The key explanatory variables examined are as follows:

- 'National background' is proxied by two country specific variables (degree of 
federal polity, using the Hooghe, Marks, Schakel (2010) Regional Authority Index; and country size), based on the survey respondent's main nationality, an indicator of whether the individual has multiple nationalities, and whether he or she was educated abroad.

- 'Pre-recruitment socialisation' is captured by pre-Commission professional experience in national administration or the private sector.

○ 'Post-recruitment socialisation' is measured by variables used in previous studies -- years of service in the Commission, staff category, experience of horizontal mobility across DGs, experience of a political role (i.e. service in a cabinet) - to which have been added two further measures. First, unlike previous studies, which focused exclusively on Commission staff working in Brussels, 'Facing the Future' looked at the experience employees based outside Brussels. Hence, indicators are included for location in Luxembourg, and in Commission representations or EU delegations internationally. Following reports of higher levels of socialization at headquarters in private sector organisations that are based at multiple sites, location outside Brussels is included as a test for an 'HQ effect' in the context of an international public administration. Second, levels of engagement in the workplace are a key indicator of experience relevant to postrecruitment socialisation, but are possibly linked to an increased association with the values of the organisation. Following the Commission (2013), an engagement index was constructed to capture the experience of working in the Commission using responses to six questions as follows: ‘ have a clear 
understanding of what is expected from me at work'; 'My colleagues are committed to doing quality work'; 'I have recently received recognition or praise for good work'; 'My manager seems to care for me as a person'; 'I have the information, material and resources to my job well'; 'At work, my opinions seem to count'; 'My line manager helps me to identify my training and development needs'.

- 'Positional advantage' is proxied according to the main responsibilities of the DG in which each member of staff works. A 'power DG' is defined according to competencies based on formal Treaty rules (Börzel 2005); a 'management DG' has important internal responsibilities.

- Controls for economic and social philosophies, educational background, nationality and gender were included.

The models include a large number of explanatory variables, some of which may be correlated with each other. To test for multicollinearity, the extent of correlations was examined using a correlation matrix for all explanatory variables included in the model. Although some variables are related, none are highly correlated. The highest correlations were: +0.629 between working at the Joint Research Centre (JRC) and holding a management position; and -0.549 between the Regional Authority Index and holding nationality of one of the EU13. The robustness of these findings was tested with respect to composition of the sample, the estimation method, and by excluding the explanatory variables that are more highly correlated from the model. The results, available on request from the authors, show the findings are not affected. 
The hypotheses are as follows:

H1: Pre-recruitment socialization - national background. Staff from federal countries are more used to delegated authority, those from smaller countries may have a stronger appreciation of the transnational economies of scale generated by the EU, those with international education experience or multiple nationalities are more likely to have international outlooks.

H2: Pre-recruitment socialization - professional background. Staff with experience in the private sector are likely to be more international in outlook; those with experience in national administration are less likely.

H3: Post-recruitment socialization. Those in more senior positions, with longer service or with broader experience within the Commission, are likely to have a stronger identification with the organisation. Those working in Brussels may have a stronger identification with the core mission of the Commission. Staff who are strongly engaged in their work are more likely to associate with the organisational values.

H4: Positional advantage: staff based in DGs that have strong competencies are more likely to be 'supranationalist'. 
The nature of the data - many individuals working in the same DG; staff from the same country - requires account to be taken of the possible correlations within DG or nationality and the consequent effects upon the standard errors. With outcome variables and many explanatory variables measured at the individual level (level 1), the DG level (level 2) and the member state level (level 3), it is necessary to estimate 3-level regression and logit models. The DG level was never significant and the member state level was only significant when using the first measure.

Our dependent variables are as follows:

- 'Where would you place yourself on the question of European integration?' (0 Union of sovereign states, 10 - EU supranational state) is modelled using a multilevel regression model.

O 'Why did you choose to follow a career in the Commission?' Respondents answering 'commitment to Europe' is modelled as a multi-level binary dependent variable, where $1=$ 'Yes' and $0=$ all other responses.

- 'As an employee of the Commission, I see my role above all else, as working for the interests of the EU' is modelled as a multi-level binary dependent variable, where 1 - strongly agree or agree and $0=$ all other responses.

Estimated coefficients for each of the three models are reported in Table 2. As both regression and binary dependent variable models are used, the coefficients are, of 
course, not directly comparable.

\section{TABLE 2}

\section{Findings}

The findings for each of these hypotheses are as follows:

H1: Pre-recruitment socialization - national background. The results for the three measures confirm that national background, particularly when measured by an index of federalism or country size, is important. Staff from federal polities are more likely to show pro-European preferences across all three measures: belief, motivation and role conception. There are two countries - Germany and Belgium - where regional authority is significantly higher than elsewhere in the EU28. These countries are also important in other ways: Germany is the largest country and Belgium has the highest number of its nationals working in the Commission. When Germany and Belgium are excluded, the finding that staff from more federal polities hold stronger supranationalist views is unchanged, but the result on country size is no longer significant. Staff educated outside their nation state are more likely to exhibit pro-European leanings on motivation and actor role conception only.

H2: Pre-recruitment socialization - professional background. Staff with national administrative experience are less likely to show pro-European preferences in terms of belief and actor role conception, but are more likely so to do on 
motivation. Respondents with private sector experience are more likely to exhibit pro-European leanings on 'commitment to Europe' and 'working in the interests of Europe'.

H3: Post-recruitment socialization. Experience in the Commission is strongly significant on the first and third measures, though the effect is non-linear. More recent recruits are more likely to support a supranational view of European integration but the effect diminishes with years of service. Staff with longer careers in the Commission were more likely to agree that they saw themselves as working in the interests of the EU, though again the effect diminishes with years of service. Seniority and staff category matter in all three models, though not in the same way. AD officials and managers are more likely to support a supranational vision of integration and were motivated by a 'commitment to Europe' when joining the Commission, but assistants, contract agents and, particularly, SNEs prefer a union of sovereign states and were less likely to have been motivated by a 'commitment to Europe'. Management ADs are more likely than non-management ADs to have pro-European leanings in motivation and role conception. However, contract and temporary agents were more likely than non-management ADs to see themselves as working in the interests of the EU. Since their preferences concerning European integration and their motivations for joining the organization were so different from those of administrators, working for the Commission appears to have had a socializing effect. 
Location also emerges as a factor. Staff based in Luxemburg or in representations abroad are less likely than those in Brussels to support a supranational view of European integration and less likely to have joined the Commission due to 'commitment to Europe'. Since roles are similar and some DGs (for example, ECFIN and CNECT) straddle Brussels and Luxembourg, the result suggests an 'HQ effect'. There is little support for the argument that preferences are shaped by different experiences with the Commission experience in a cabinet or high levels of horizontal mobility -- although respondents who have worked in more than one DG are more likely to agree that they see themselves as 'working in the interests of the EU', suggestive that a wider range of experience has a socializing effect in terms of identifying with the key mission. Staff who are engaged in their work are more likely to exhibit proEuropean organizational values across all three measures.

H4: Positional advantage. No evidence is found that staff in DGs with particular responsibilities or EU competencies are likely to be more 'supranationalist'.

Controls: Respondents with post-graduate qualifications were likely to show 'supranationalist' preferences across all three measures: belief, motivation and role conception. Staff with a legal or political science education are more 'proEuropean' in their outlook across all three measures. Those with more economically liberal philosophies are less likely to hold a supranational view of 
European integration and those who are more socially conservative are less likely to be 'pro-European' across all three measures. Women are less likely to be 'proEuropean' across all three measures. Finally, staff from EU13 member states are more likely to support a supranational view of European integration and to see themselves as 'working for the EU' than those from other member states.

\section{Discussion}

The findings show that the beliefs and values held by Commission personnel vary between staff groupings - the first time that data making the detection of such differences possible has been available. Although important in itself, this result has wider significance. It underlines the value of representative sampling in the study of complex organizations and highlights the limitations of findings based on data drawn from single groupings or strata. It is not only that, in the absence of information about all staff groupings, the extent to which such findings can be generalized cannot be established to a high level of satisfaction, but that investigating a single grouping limits the range of experiences that can be tested. In other words, without data that allows comparisons between staff groupings, it is not possible to test whether membership of a particular staff grouping is itself a factor.

The findings also demonstrate the value of a broader approach to 'supranationalism' than typically taken in the existing literature. If the aim is to determine the impact of working in the Commission, it is important to countenance the possibility that individuals and sub-groups of individuals may be affected in different 
ways. Some may develop a preference for a particular model of EU governance, some a motivation for working to build Europe, and others a role conception. That different staff groupings score higher on some measures than others, it seems reasonable to infer that a test that goes beyond a single dimension is necessary to capture impact on beliefs and values.

Finally, the combination of data drawn from across the entire Commission workforce with a broader test for 'supranationalism', produces a more nuanced picture than existing studies. Whereas the pre-recruitment socialization school, which focuses on officials, argues that national experiences are pre-dominant and post-recruitment socialization, which concentrates on SNEs, that working in the Commission has an effect, the results reported above show that both are important. But what of magnitude? The range of difference in 'supranationalism' (first measure) between a member of staff from a country with the highest and lowest level of federalism is +2 points, between the member of staff with the shortest and longest years of experience in the Commission +1.72 points and between a non-management $A D$, an AST, temporary agent, contract agent and an SNE $-0.49,-0.58,-0.67$ and -1.1 points respectively. While not quite squaring the circle, the results underline the value of a genuinely representative sample.

\section{Conclusion}

While the early literature on the beliefs of Commission officials was characterised by assumptions or speculative theorising, a more recent scholarship has used empirical evidence to test from a variety of sub-disciplinary perspectives propositions about the 
beliefs that bureaucrats hold. Despite the important advances it has brought, and its marked sophistication in relation to the earlier literature, empirical studies of the Commission's socializing power has been marked by three shortcomings: the measures of the values that are its central concern; the narrowness of the sample population on which studies have been based; and the range of variables authors have been able to test.

Drawing on representative data of scope and scale that has not been available hitherto, this article has sought to address these shortcomings and to advance understanding of the beliefs of Commission staff and the influences that shape them. It has introduced new and more intuitive measures of 'supranationalism'. It has mapped beliefs across all Commission staff groups, and it has used the 'Facing the Future' data to test existing explanatory variables from previous studies, as well as new variables -most notably, staff grouping.

More broadly, the paper has sought to move beyond the limitations of the existing debate and to deliver three important findings. First, by experimenting with separate and discrete measures of 'supranationalism', and by showing that responses do not always co-vary, it has shown that the definition used in empirical surveys does matter. The lesson is that considerable caution needs to be exercised when formulating questions for respondents, interpreting their responses as values, and defining the dependent variable. Second, the article shows that the beliefs held by employees vary across different staff groupings, often significantly. The finding that levels of commitment to 'supranationalism' reinforces the point that generalizations based on a 
narrow sample are unlikely to be robust. While the views of administrators tend to be unusual compared to other staff groupings, those of managers and especially senior managers - a subgrouping of administrators -- are even more atypical.

Furthermore, the article demonstrates that, when controls are introduced for national background, there is evidence that other factors still play a role in shaping beliefs. In other words -- and important, since it challenges the conventional wisdom -post-recruitment experience in the Commission does have an influence. National backgrounds play a part, but working in the organization also has an impact. Analysis of the views of all staff groups shows that proponents of the two main theoretical perspectives have to some extent been arguing past each other - an eventuality that was not discernable when only the beliefs of 'senior managers' or SNEs were examined, but that international institutions do have a socializing influence after all. One of the many roads to international norms does indeed run through Brussels

Finally, the study has wider implications for research on EU institutions and other international bodies. In attempting to assess the socializing power of institutions, a research programme must be able to capture the multiple ways in which the experience of working for an organization can have a cognitive or affective impact on individuals. It raises questions about the mechanisms of organizational socialization, the conditions under which it takes place, whether some individuals are more susceptible, and whether some organizations succeed better than others. It also suggests that it may be worthwhile to revisit whether beliefs influence behaviour or affect outcomes. 


\section{Acknowledgements}

We thank the anonymous referees who offered constructive comments, and to our friends, Françoise Girard and David G. Knott, whose generosity made the fieldwork possible. Our greatest debt is to the Commission staff who allowed their views to be canvassed.

\section{References}

Aberbach, J.D., R.D. Putnam and B.A. Rockman, 1981. Bureaucrats and Politicians in Western Democracies. Harvard: Harvard University Press.

Bauer, M. W. 2012. 'Tolerant if personal goals remain unharmed: Explaining supranational bureaucrats' attitudes to organizational change', Governance, 25, 3, 485510.

Bes, B. J. 2013. 'The role conceptions of senior Commission officials: the persistent influence of national factors', paper at the $7^{\text {th }}$ ECPR General Conference 4 - 7 September, Bordeaux, France

Börzel, T. 2005.'Mind the gap! European integration between level and scope', Journal of European Public Policy, 12, 2, 217-236.

Checkel, J. 2005. 'International institutions and socialization in Europe. Introduction and framework', International Organization, 59, 4, 801-826.

Christiansen, T., Jorgensen, K.E. and Weiner, A. (1999). 'The social construction of Europe', Journal of European Public Policy, 6,4, 528-44

Connolly, S. and Kassim, H. (2015) Ch 11 'The permanent Commission bureaucrat' in 
M.W. Bauer and J. Trondal (eds) Palgrave Handbook of the European Administrative System, Palgrave: Basingstoke, 161-187

Cram, L. 1993. 'Calling the tune without paying the piper? Social policy regulation: the role of the Commission in European Community social policy', Policy and Politics, 21, 2, 135-146.

Dehousse, R. and A. Thompson 2012. 'Intergovernmentalists in the Commission: Foxes in the Henhouse?', Journal of European Integration, 34, 2, 113-132.

European Commission, 2013. Staff survey 2013. Survey results. Brussels: DG Human Resources and Security.

Franchino, F. 2007. The Powers of the Union. Delegation in the EU. Cambridge: Cambridge University Press.

Haas, E.B. 1958. The Uniting of Europe. Stanford, CA: Stanford University Press. Hooghe L., 1999a. 'Images of Europe: orientations to European integration among senior officials of the Commission', British Journal of Political Science, 29, 2, 345-367. Hooghe 1999b, 'Supranational activists or intergovernmental agents? Explaining the orientations of senior commission officials towards European integration', Comparative Political Studies, 32, 4, 435-463.

Hooghe, L. 2002. The European Commission and the Integration of Europe: Images of Governance. Cambridge: Cambridge University Press.

Hooghe, L. 2005. 'Several roads lead to international norms, but few via international socialization: a case study of the European Commission', International Organization, 59, 4, 861898 . 
Hooghe, L., J. Marks and A. Schakel, 2010. The Rise of Regional Authority: A Comparative Study of 42 Democracies. London: Routledge.

Hooghe, L., 2012. 'Images of Europe: how commission officials conceive their institution's role', Journal of Common Market Studies, 50, 1, 87-111.

Jupille, J. 2004. Procedural Politics Issues, Influence and Institutional Choice in the European Union. Cambridge: Cambridge University Press.

Kassim, H., J. Peterson, L. Hooghe, M. Bauer, S. Connolly, R. Dehousse, and A.

Thompson, 2013. The European Commission in the $21^{\text {st }}$ Century. Oxford: Oxford University Press.

Lindberg, L.N. (1963) The Political Dynamics of European Integration, Stanford, CA: Stanford University Press

Murdoch, Z. and B. Geys, 2012. 'Instrumental calculation, cognitive role-playing, or both? Self-perceptions of seconded national experts in the European Commission', Journal of European Public Policy, 19, 9, 1357-1376.

Murdoch, Z. and J. Trondal, J, 2013.' Contracted government: Unveiling the European Commission's contracted staff', West European Politics, 36, 1, 1-21.

Pollack, M.A. 2003. The Engines of European Integration. Delegation, Agency, and Agenda Setting in the EU. Oxford: Oxford University Press.

Scully, R. 2005. Becoming Europeans? Attitudes, Behaviour, and Socialization in the European Parliament. Oxford: Oxford University Press

Suvarierol, S., M. Busuioc and M. Groenleer, 2013. 'Working for Europe? Socialisation in the European Commission and Agencies of the European Union', Public Administration, 
$91,4,908-927$.

Trondal, J. 2001. 'The parallel administration of the European Commission: National officials in European clothes?', paper presented at ECPR Joint Sessions. Grenoble.

Trondal, J. 2006. 'Governing at the frontier of the European Commission: The case of seconded national officials', West European Politics, 29, 1, 147-160.

Trondal J. 2007. 'Is the European Commission a 'hothouse' for supranationalism?

Exploring actor-Level supranationalism', Journal of Common Market Studies, 45, 5, 1111-1133.

Trondal, J. 2008. 'Balancing roles of representation in the European Commission', Acta Politica, 43, 4, 429-452.

Trondal, J. 2010. An Emergent European Executive Order. Oxford: Oxford University Press.

Trondal, J., C. Van den Berg and S. Suvarierol, 2008. 'The compound machinery of government: The case of seconded national officials in the European Commission', Governance, 21, 2, 253-274. 
TABLE 1 Summary of previous studies of the European Commission

\begin{tabular}{|c|c|c|c|c|}
\hline Author & Period & Sample size & Dependent variable and method & Commission Staff category \\
\hline $\begin{array}{l}\text { Hooghe, } \\
\text { 1999a and } \\
\text { 1999b }\end{array}$ & 1995-7 & $\begin{array}{c}106 \\
\text { Semi-structured interviews }\end{array}$ & $\begin{array}{l}\text { - Factor analysis: officials should speak for general EU interest; egalitarian/free } \\
\text { market; technocratic or democratic; intergovernmentalism or } \\
\text { supranationalism } \\
\text { - } \quad \text { Supranationalism based on } 3 \text { questions on orientation towards European } \\
\text { integration } \\
\text { - } \quad \text { Ordinary Least Squares }\end{array}$ & $\begin{array}{l}\text { Senior officials (Directors } \\
\text { General, Deputy Directors } \\
\text { General, Directors, Senior } \\
\text { Advisors) }\end{array}$ \\
\hline $\begin{array}{l}\text { Hooghe, } \\
2005\end{array}$ & 2002 & $\begin{array}{l}\qquad \begin{array}{l}198=105(1997)+93 \\
(2002)\end{array} \\
\text { Semi-structured interviews }\end{array}$ & \multirow{2}{*}{$\begin{array}{l}\text { - Supranationalism derived from: 'The Commission should be the government } \\
\text { of Europe' and 'Member states should be the central pillars of the EU' } \\
\text { - State centric, supranationalists, institutional pragmatists } \\
\text { - Binary choice outcomes }\end{array}$} & $\begin{array}{l}\text { Senior officials and Heads of } \\
\text { Cabinet }\end{array}$ \\
\hline $\begin{array}{l}\text { Hooghe, } \\
2011\end{array}$ & 2008 & $\begin{array}{c}1648 \\
\text { Online survey } \\
(130 \text { senior officials) }\end{array}$ & & AD policy officials \\
\hline Bes, 2013 & $\begin{array}{l}1995-7 \\
2002 \\
2008\end{array}$ & $\begin{array}{c}105 \text { (1995-7), } 93(2002), \\
130(2008)\end{array}$ & $\begin{array}{ll}\text { - } & \text { Revises Hooghe (2011) typology: state centric, leaning state centric, } \\
\text { institutional pragmatists, leaning supranationalists, supranationalist } \\
\text { - } \quad \text { Ordered logit }\end{array}$ & $\begin{array}{l}\text { Senior officials and Heads of } \\
\text { Cabinet }\end{array}$ \\
\hline $\begin{array}{l}\text { Trondal, } \\
2006\end{array}$ & 2005 & \multirow{2}{*}{$\begin{array}{l}71 \text { (survey) + } 22 \\
\quad \text { (interview) }\end{array}$} & \multirow{2}{*}{$\begin{array}{l}\text { - } \quad \text { Four loyalties: intergovernmental, supranational, departmental, epistemic } \\
\text { - } \quad \text { Perceptions of loyalty towards the Commission as a whole and towards the } \\
\text { Director General of their DG and attitude change } \\
\text { - } \quad \text { Correlation and Ordinary Least Squares }\end{array}$} & \multirow{2}{*}{$\begin{array}{l}\text { Seconded National Experts from } \\
\text { member states, Norway and } \\
\text { Iceland }\end{array}$} \\
\hline $\begin{array}{l}\text { Trondal, } \\
2007\end{array}$ & 2005 & & & \\
\hline $\begin{array}{l}\text { Bauer, } \\
2012\end{array}$ & 2008 & $\begin{array}{c}707 \\
\text { Online survey }\end{array}$ & $\begin{array}{l}\text { - We would like to ask your views on recent administrative reforms. Thinking } \\
\text { of the administrative reforms implemented since 2000, what are your views } \\
\text { on the following statements?' } \\
\text { - Principal Component Analysis } \\
\text { - Ordinary Least Squares }\end{array}$ & $\begin{array}{l}\text { AD policy officials who joined } \\
\text { the Commission before } 2000\end{array}$ \\
\hline $\begin{array}{l}\text { Suvarierol, } \\
\text { et al } 2013\end{array}$ & $2005-11$ & $\begin{array}{c}279 \\
\text { Pooled } 4 \text { sources } \\
\text { Interviews and surveys }\end{array}$ & $\begin{array}{l}\text { - Official shall carry out the duties assigned to him objectively, impartially and } \\
\text { in keeping with his duty of loyalty to the Communities } \\
\text { - Commission: Serving the people of Europe } \\
\text { - } \quad \text { Agencies: Working for us } \\
\text { - } \quad \text { Qualitative }\end{array}$ & $\begin{array}{l}82 \text { officials in Social Regulation } \\
\text { DGs }+90 \text { Dutch Seconded } \\
\text { National Experts }+67 \text { agency } \\
\text { staff }+40 \text { (management board } \\
\text { representatives, agency }\end{array}$ \\
\hline
\end{tabular}




\begin{tabular}{|l|l|l|l|l||}
\hline & & & & \\
\hline
\end{tabular}


FIGURE 1 European Commission workforce by staff category (2014)

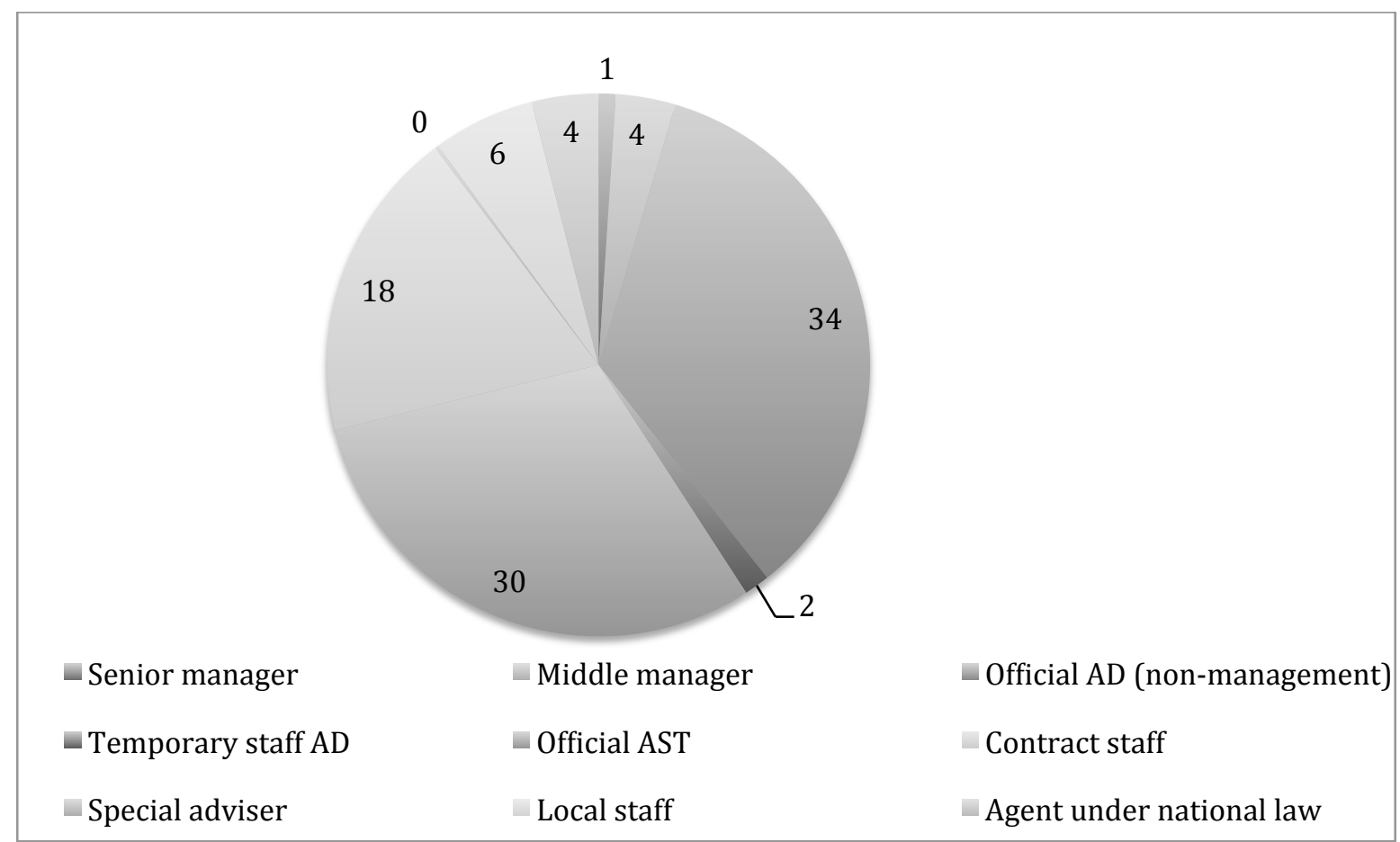

Source: European Commission DG HR, 2015 
FIGURE 2 'Where would you place yourself on the question of European integration?' 0 - Union of sovereign states; 10 - EU supranational state. (Means)

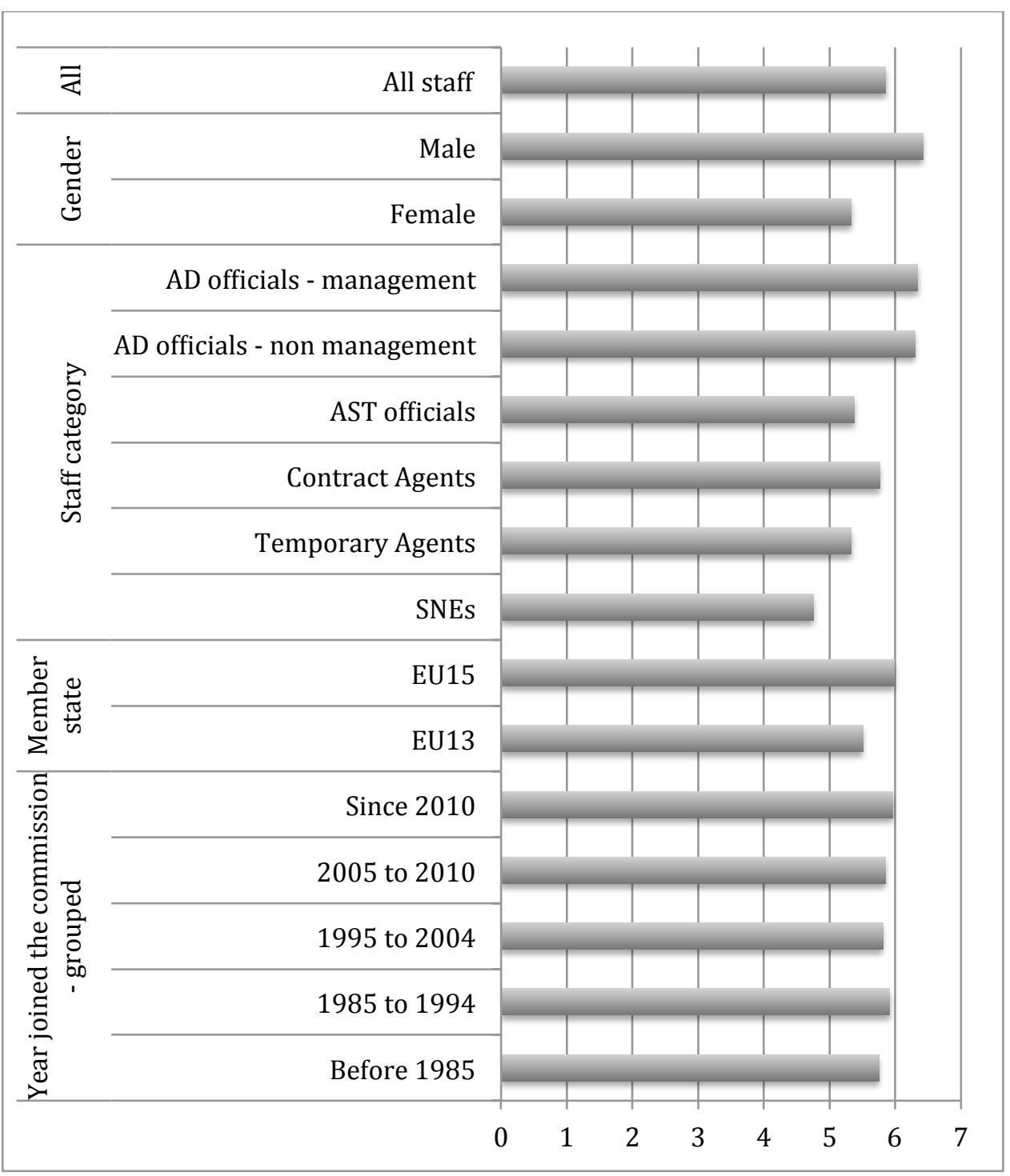


FIGURE 3 'Why did you choose to follow a career in the Commission?' Commitment to Europe

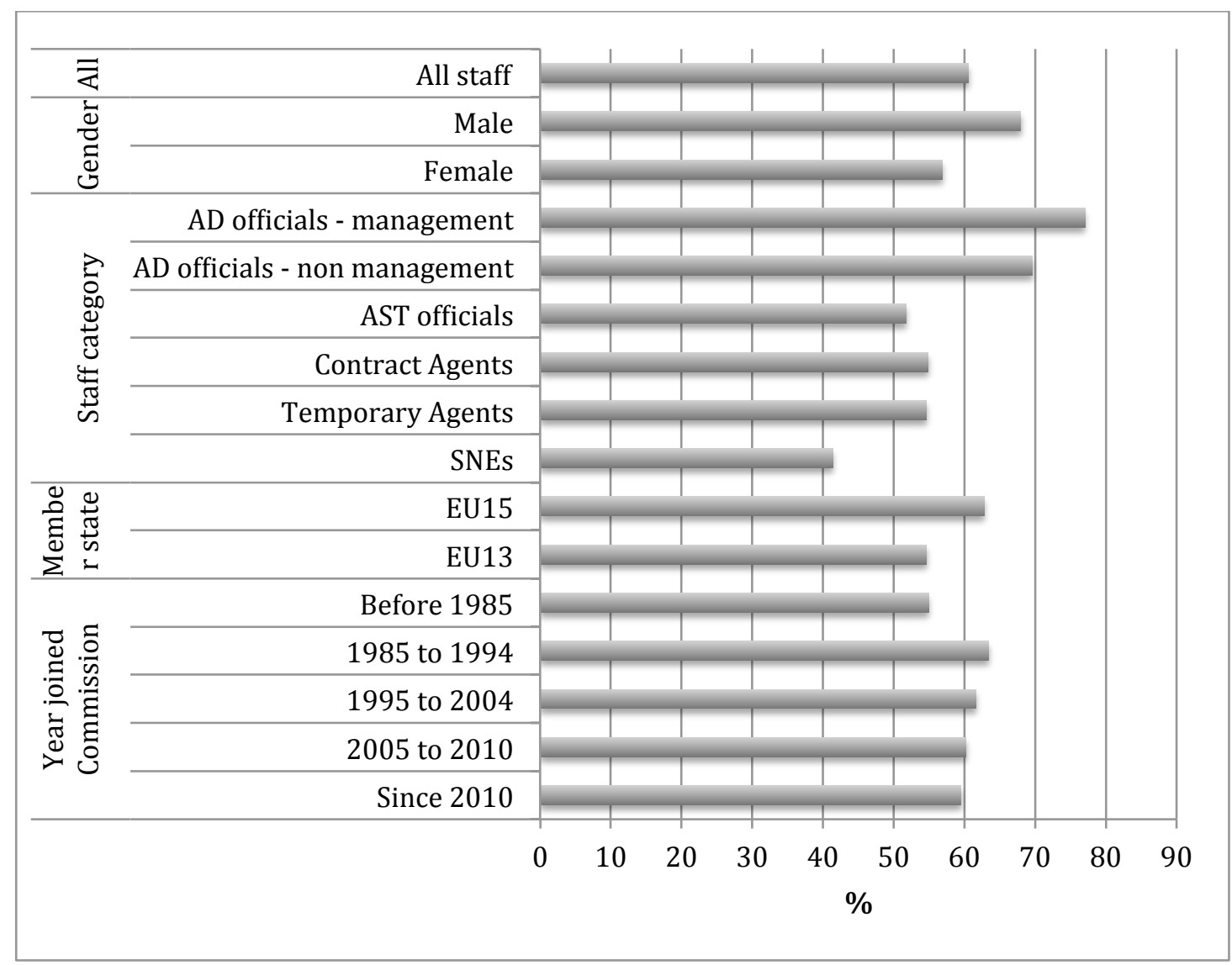


FIGURE 4 'As an employee of the Commission, I see my role above all else, as working for the interests of the EU.'

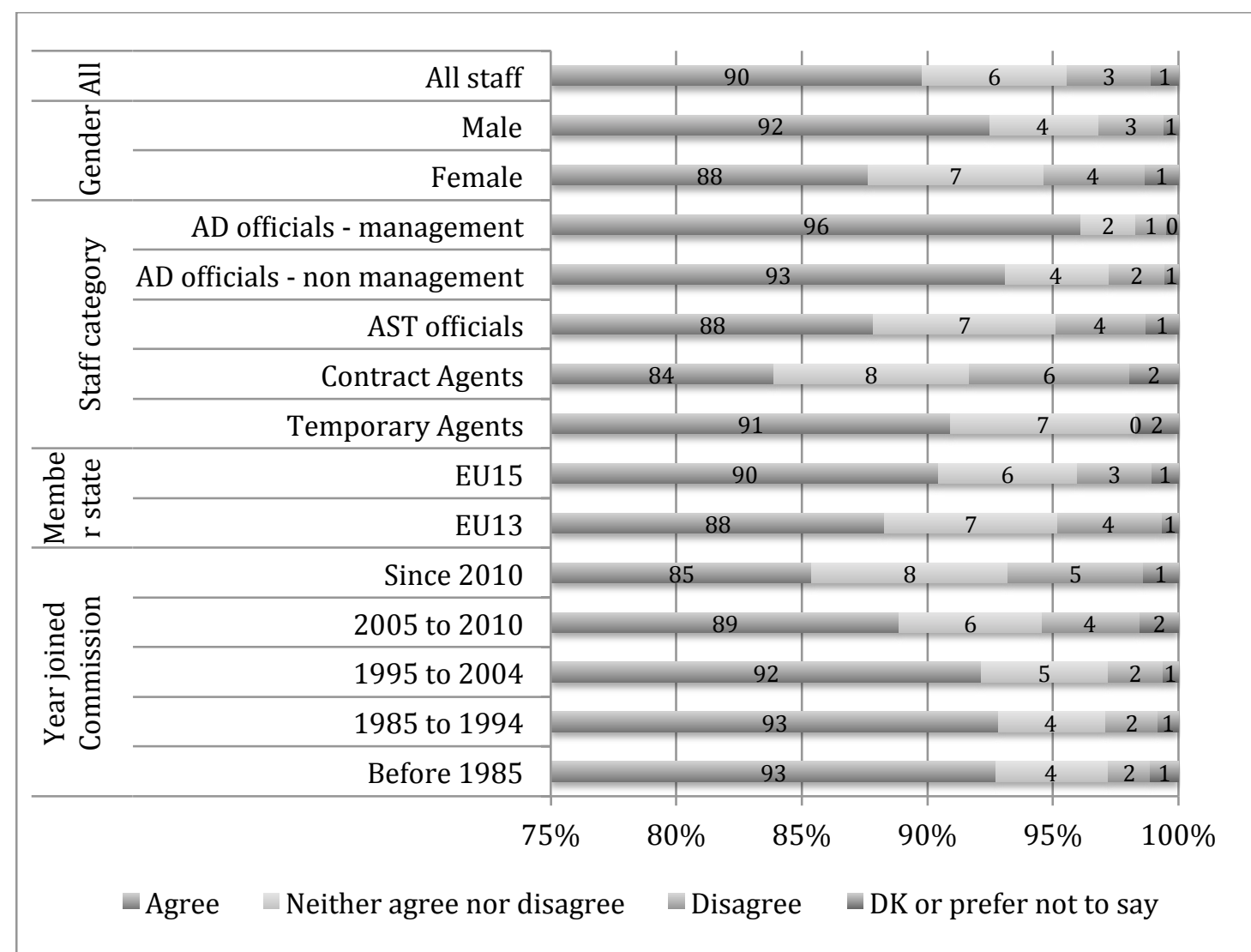

*not asked of Seconded National Experts 
TABLE 2 Summary of results

\begin{tabular}{|c|c|c|c|c|c|c|c|c|c|c|}
\hline \multicolumn{2}{|l|}{ Measure } & \multicolumn{3}{|c|}{$\begin{array}{l}1-\text { belief } \\
\text { Mixed effect, multi-level } \\
\text { regression }\end{array}$} & \multicolumn{3}{|c|}{$\begin{array}{c}2 \text { - motivation } \\
\text { Mixed effect, multi- } \\
\text { level logit }\end{array}$} & \multicolumn{3}{|c|}{$\begin{array}{c}3-\text { role conception } \\
\text { Mixed effect, multi-level } \\
\text { logit }\end{array}$} \\
\hline & & Coef & St Error & Sig. & Coef & St Error & Sig. & Coef & St Error & Sig. \\
\hline \multirow{4}{*}{ National background } & Federalism index & 0.07 & 0.01 & $* * *$ & 0.02 & 0.00 & $* * *$ & 0.02 & 0.01 & $* * *$ \\
\hline & Country size & -0.13 & 0.04 & $* * *$ & 0.12 & 0.03 & $* * *$ & 0.01 & 0.05 & \\
\hline & Educated outside of nation state & 0.13 & 0.09 & & 0.29 & 0.08 & $* * *$ & 0.43 & 0.13 & $* * *$ \\
\hline & Multiple nationality & 0.09 & 0.14 & * & 0.19 & 0.13 & & 0.31 & 0.22 & \\
\hline \multirow{2}{*}{$\begin{array}{l}\text { Pre-recruitment } \\
\text { socialisation }\end{array}$} & National administration experience & -0.17 & 0.09 & * & 0.15 & 0.08 & * & -0.22 & 0.12 & * \\
\hline & Private sector experience & 0.14 & 0.09 & & 0.27 & 0.08 & $* * *$ & 0.22 & 0.12 & $*$ \\
\hline \multirow{16}{*}{$\begin{array}{l}\text { Post-recruitment } \\
\text { socialisation }\end{array}$} & Number of years worked in the Commission & -0.08 & 0.02 & $* * *$ & -0.03 & 0.02 & $* *$ & 0.16 & 0.02 & $* * *$ \\
\hline & Square of years worked in the Commission & 0.00 & 0.00 & $* * *$ & 0.00 & 0.00 & & 0.00 & 0.00 & $* * *$ \\
\hline & Management AD & -0.02 & 0.15 & & 0.27 & 0.14 & $*$ & 0.62 & 0.31 & ** \\
\hline & Non-management AD (reference) & - & - & - & - & - & - & - & - & - \\
\hline & AST & -0.49 & 0.11 & $* * *$ & -0.40 & 0.09 & $* * *$ & 0.12 & 0.15 & \\
\hline & Contract agent & -0.58 & 0.15 & $* * *$ & -0.65 & 0.13 & $* * *$ & 0.36 & 0.18 & $* *$ \\
\hline & Temporary agent & -0.66 & 0.31 & $* *$ & -0.29 & 0.27 & & 1.07 & 0.49 & $* *$ \\
\hline & SNE & -1.26 & 0.31 & $* * *$ & -1.20 & 0.26 & $* * *$ & & & \\
\hline & Brussels (reference) & - & - & - & - & - & - & - & - & - \\
\hline & Luxemburg & -0.32 & 0.14 & $* *$ & -0.21 & 0.12 & $*$ & -0.39 & 0.18 & $* *$ \\
\hline & JRC sites & -0.56 & 0.26 & ${ }^{* *}$ & -0.16 & 0.21 & & -0.58 & 0.34 & \\
\hline & Delegation & 0.18 & 0.22 & & -0.01 & 0.19 & & -0.14 & 0.29 & \\
\hline & Representation & -0.42 & 0.33 & & -0.25 & 0.29 & & -0.28 & 0.47 & \\
\hline & Location - Other or Prefer not to say & -0.17 & 0.35 & & -0.42 & 0.29 & & 0.05 & 0.45 & \\
\hline & Engagement Index & 0.42 & 0.17 & $* *$ & 0.46 & 0.14 & $* * *$ & 1.16 & 0.22 & $* * *$ \\
\hline & Has Cabinet experience & 0.05 & 0.22 & & 0.19 & 0.20 & & 1.16 & 0.53 & $* *$ \\
\hline
\end{tabular}




\begin{tabular}{|c|c|c|c|c|c|c|c|c|c|c|}
\hline & Worked in more than one DG & 0.04 & 0.09 & & 0.18 & 0.08 & $* *$ & 0.25 & 0.13 & \\
\hline \multirow{2}{*}{ Positional advantage } & Works in DG Power & -0.04 & 0.11 & & -0.10 & 0.10 & & 0.01 & 0.16 & \\
\hline & Works in DG Management & 0.00 & 0.17 & & 0.05 & 0.14 & & 0.16 & 0.25 & \\
\hline \multirow{19}{*}{ Controls } & Post graduate degree & 0.32 & 0.10 & $* * *$ & 0.25 & 0.08 & $* * *$ & 0.33 & 0.13 & $* *$ \\
\hline & Degree (reference) & - & - & - & - & - & & - & - & - \\
\hline & School leaving & 0.38 & 0.33 & & 0.07 & 0.26 & & -0.70 & 0.47 & \\
\hline & Vocational & -0.19 & 0.29 & & 0.26 & 0.24 & & -0.56 & 0.36 & \\
\hline & No formal qualification & -0.99 & 0.92 & & 0.62 & 0.73 & & 0.00 & 0.00 & \\
\hline & Other level & 0.22 & 0.38 & & -0.13 & 0.30 & & -0.73 & 0.44 & $*$ \\
\hline & Business or Economics & -0.39 & 0.15 & $* * *$ & -0.48 & 0.14 & $* * *$ & -0.36 & 0.24 & \\
\hline & STEMM & -0.58 & 0.16 & $* * *$ & -0.70 & 0.15 & $* * *$ & -0.51 & 0.24 & $* *$ \\
\hline & Politics (reference) & - & - & - & - & - & - & - & - & - \\
\hline & Law & -0.06 & 0.17 & & 0.13 & 0.16 & $* * *$ & -0.43 & 0.26 & $*$ \\
\hline & Humanities & -0.62 & 0.16 & $* * *$ & -0.71 & 0.15 & $* * *$ & -0.61 & 0.25 & $* *$ \\
\hline & Other social science & -0.31 & 0.25 & & -0.62 & 0.22 & $* * *$ & -0.73 & 0.34 & $* *$ \\
\hline & Other or prefer not to say & -0.82 & 0.32 & $* * *$ & -0.76 & 0.26 & $* * *$ & 0.21 & 0.47 & \\
\hline & Economic philosophy (low - govt \& high - market) & -0.09 & 0.02 & $* * *$ & -0.01 & 0.02 & & -0.03 & 0.03 & \\
\hline & Social philosophy (low - liberal \& high - conservative) & -0.09 & 0.02 & $* * *$ & -0.04 & 0.01 & $* *$ & -0.04 & 0.02 & $*$ \\
\hline & Female & -0.91 & 0.09 & $* * *$ & -0.32 & 0.08 & $* * *$ & -0.36 & 0.12 & $* * *$ \\
\hline & Gender, prefer not to say & 0.18 & 0.42 & & -0.29 & 0.34 & & -0.16 & 0.55 & \\
\hline & EU13 & 0.65 & 0.15 & $* * *$ & -0.09 & 0.12 & & 0.73 & 0.19 & $* * *$ \\
\hline & Constant & 6.67 & 0.31 & $* * *$ & 0.55 & 0.27 & $* *$ & 0.13 & 0.41 & \\
\hline \multirow{5}{*}{ Random effects } & Level 2-DG & $5.9 \mathrm{e}-13$ & $3.9 \mathrm{e}-12$ & & 0.01 & 0.01 & & 0.025 & 0.046 & \\
\hline & Level 3 - Nationality & 0.298 & .074 & $* * *$ & 0.035 & 0.04 & & 0.127 & 0.106 & \\
\hline & Residual & 5.83 & .14 & & & & & & & \\
\hline & Log-likelihood & \multicolumn{3}{|c|}{-9091.7008} & \multicolumn{3}{|c|}{-2502.0865} & \multicolumn{3}{|c|}{-1221.843} \\
\hline & Wald $\chi^{2}$ & \multicolumn{3}{|c|}{524.74} & \multicolumn{3}{|c|}{358.91} & \multicolumn{3}{|c|}{205.19} \\
\hline
\end{tabular}


* significant at $10 \%(p<0.1), * *$ significant at $5 \%(p<0.05)$ and $* * *$ significant at $1 \%(p<0.01)$. 
APPENDIX FIGURE 1a-1d ECFTF sample benchmarked against the Commission population
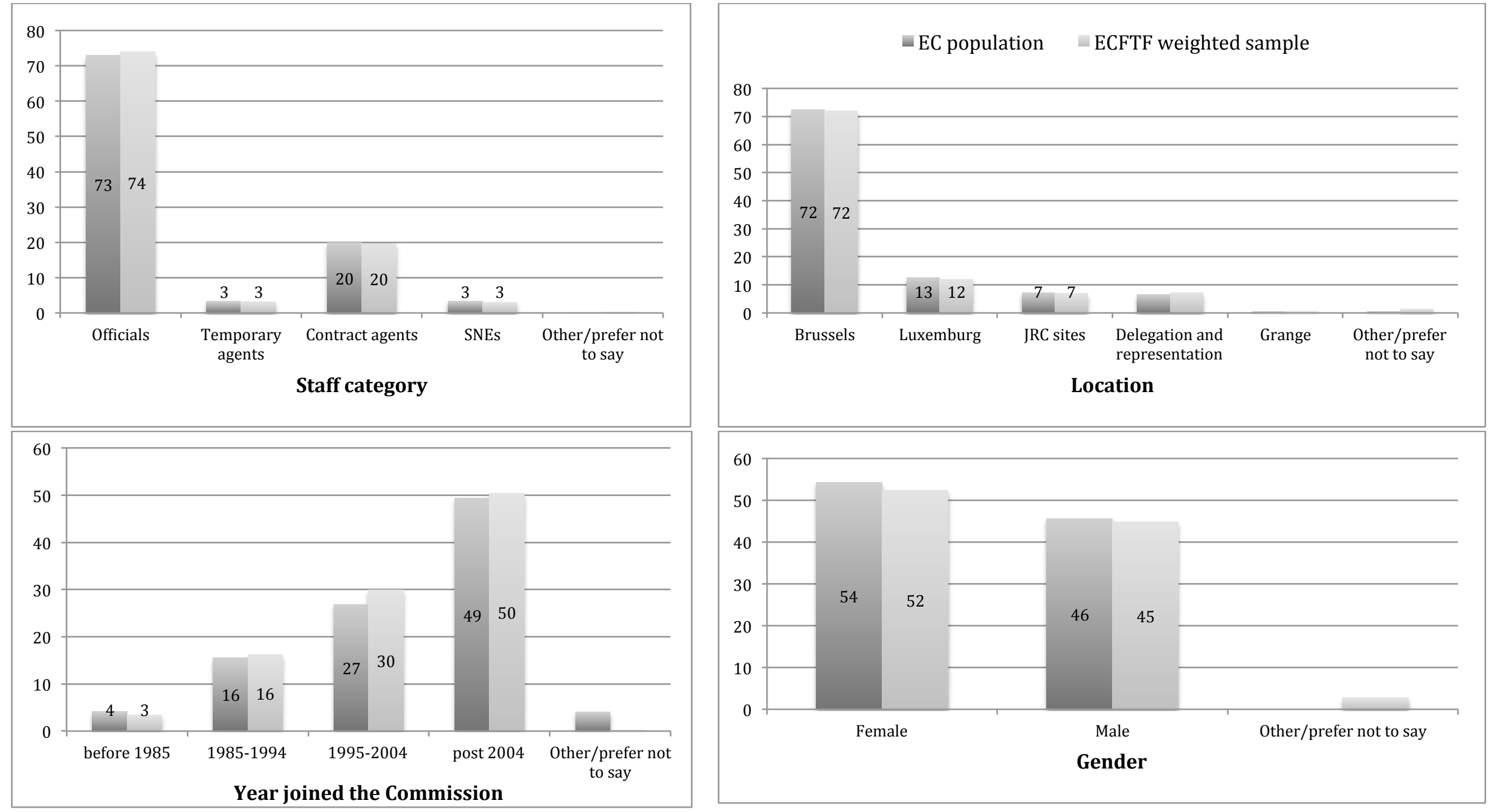
APPENDIX TABLE 1 Explanatory variables

\begin{tabular}{|c|c|c|c|c|c|}
\hline & & Min & Max & Mean & StDev \\
\hline \multirow{4}{*}{$\begin{array}{l}\text { National } \\
\text { background }\end{array}$} & Federalism index: Hooghe, Marks, Schakel (2010). & 0 & 29.4 & 16.99 & 9.177 \\
\hline & Country size: normalised Eurostat (2014) & -0.78 & 2.8 & 0.834 & 1.257 \\
\hline & Educated outside of nation state & 0 & 1 & 0.392 & 0.488 \\
\hline & Multiple nationality & 0 & 1 & 0.083 & 0.276 \\
\hline \multirow{2}{*}{$\begin{array}{l}\text { Pre- } \\
\text { recruitment } \\
\text { socialisation }\end{array}$} & National administration experience & 0 & 1 & 0.32 & 0.47 \\
\hline & Private sector experience & 0 & 1 & 0.53 & 0.50 \\
\hline \multirow{21}{*}{$\begin{array}{l}\text { Post- } \\
\text { recruitment } \\
\text { socialisation }\end{array}$} & Years working in the Commission & & & & \\
\hline & Number of years & 1 & 54 & 11.72 & 8.69 \\
\hline & Square of years & 1 & 2916 & 212.9 & 274.8 \\
\hline & Staff grouping & & & & \\
\hline & Management AD & 0 & 1 & 0.08 & 0.28 \\
\hline & Non-management $A D$ & 0 & 1 & 0.35 & 0.48 \\
\hline & AST & 0 & 1 & 0.31 & 0.46 \\
\hline & Contract agent & 0 & 1 & 0.14 & 0.35 \\
\hline & Temporary agent & 0 & 1 & 0.02 & 0.13 \\
\hline & SNE & 0 & 1 & 0.02 & 0.14 \\
\hline & Location & & & & \\
\hline & Brussels & 0 & 1 & 0.70 & 0.46 \\
\hline & Luxemburg & 0 & 1 & 0.12 & 0.32 \\
\hline & JRC sites & 0 & 1 & 0.07 & 0.26 \\
\hline & Delegation & 0 & 1 & 0.05 & 0.21 \\
\hline & Representation & 0 & 1 & 0.01 & 0.12 \\
\hline & Other/Prefer not to say & 0 & 1 & 0.02 & 0.13 \\
\hline & Engagement Index: Commission, (2013) & 0.14 & 1 & 0.67 & 0.25 \\
\hline & Commission experience & & & & \\
\hline & Cabinet experience & 0 & 1 & 0.03 & 0.18 \\
\hline & Worked in more than one DG & 0 & 1 & 0.51 & 0.50 \\
\hline \multirow{2}{*}{$\begin{array}{l}\text { Positional } \\
\text { advantage }\end{array}$} & DG Power: five-point scale based on Börzel, (2005) & 0 & 1 & 0.28 & 0.45 \\
\hline & Anti-Fraud Office, Secretariat-General & 0 & 1 & 0.15 & 0.35 \\
\hline \multirow{12}{*}{$\begin{array}{l}\text { Highest } \\
\text { qualification }\end{array}$} & Highest qualification & & & & \\
\hline & Post-graduate & 0 & 1 & 0.571 & 0.495 \\
\hline & University degree & 0 & 1 & 0.290 & 0.454 \\
\hline & School leaving qualification & 0 & 1 & 0.067 & 0.250 \\
\hline & Vocational qualification & 0 & 1 & 0.022 & 0.145 \\
\hline & No formal qualification & 0 & 1 & 0.003 & 0.050 \\
\hline & Other or prefer not to say & 0 & 1 & 0.047 & 0.212 \\
\hline & Subject of highest qualification & & & & \\
\hline & Business or Economics & 0 & 1 & 0.24 & 0.43 \\
\hline & STEMM & 0 & 1 & 0.21 & 0.41 \\
\hline & Politics & 0 & 1 & 0.13 & 0.33 \\
\hline & Law & 0 & 1 & 0.11 & 0.32 \\
\hline
\end{tabular}




\begin{tabular}{||l|l|cc|cc|}
\hline \hline \multirow{5}{*}{} & Humanities & 0 & 1 & 0.16 & 0.37 \\
& Other social science & 0 & 1 & 0.03 & 0.18 \\
Philosophic & Other or prefer not to say & & 0 & \\
al values & Economic (low - government, high - market) & 0 & 1 & 0.13 & 0.33 \\
& Social and cultural (low - liberal, high conservative) & 0 & 10 & 4.85 & 2.21 \\
Gender & Male & 0 & 10 & 3.06 & 2.41 \\
& Female & 0 & 1 & 0.480 & 0.500 \\
Member & Prefer not to say & 0 & 1 & 0.46 & 0.50 \\
state & EU13 & 0 & 1 & 0.03 & 0.16 \\
& EU15 & 0 & 1 & 0.15 & 0.35 \\
& Other or prefer not to say & 0 & 1 & 0.76 & 0.42 \\
\hline \hline
\end{tabular}

Note: 1 - Yes, 0 - No 